\title{
Effect of Chitosan Powder Prepared from Snail Shells to Remove Lead (II) Ion and Nickel (II) Ion from Aqueous Solution and Its Adsorption Isotherm Model
}

\author{
Olayinka John Akinyeye ${ }^{1}$, Tope Babatunde Ibigbami ${ }^{2}$, Oluwakayode Odeja ${ }^{3}$ \\ ${ }^{1}$ Engineering Materials Research Department, Nigerian Building and Road Research Institute, Sango Ota, Ogun State, Nigeria \\ ${ }^{2}$ Healthy Life for All Foundation, University College Hospital Ibadan, Oyo State, Nigeria \\ ${ }^{3}$ Federal University of Petroleum Resources, Effurum, Delta State, Nigeria \\ Email address: \\ akinyeyeolayinka@gmail.com (O. J. Akinyeye), tbabs04@gmail.com (T. B. Ibigbami), kayodeja1@yahoo.com (O. Odeja)
}

\section{To cite this article:}

Olayinka John Akinyeye, Tope Babatunde Ibigbami, Oluwakayode Odeja. Effect of Chitosan Powder Prepared from Snail Shells to Remove Lead (II) Ion and Nickel (II) Ion from Aqueous Solution and Its Adsorption Isotherm Model. American Journal of Applied Chemistry. Vol. 4, No. 4, 2016, pp. 146-156. doi: 10.11648/j.ajac.20160404.15

Received: April 13, 2016; Accepted: May 17, 2016; Published: July 28, 2016

\begin{abstract}
The toxic effects of heavy metals have remained a major source of concern globally because of their nonbiodegradable nature which makes heavy metal pollution a serious environmental problem. The extents of removal for two heavy metals were investigated on adsorbent dose, temperature, $\mathrm{pH}$, contact time and initial metals ion concentration. Maximum adsorption was obtained at $\mathrm{pH} 5$ for $\mathrm{Pb}^{2+}$ ion and $\mathrm{pH} 7$ for $\mathrm{Ni}^{2+}$ ion with $82.1 \%$ and $68.28 \%$, at maximum adsorption temperature $335 \mathrm{~K}$ and $355 \mathrm{~K}$ for both metal ions with $87 \%$ and $80 \%$ metal removal respectively. The study shows that initial metal ion concentration and adsorbent dose on metals adsorption increases for both metal ions having a maximum adsorption dose at $99.93 \%$ and $70.58 \%$ removal at $180 \mathrm{mins}$ contact time for both metal ions with $99.83 \%$ and $70.37 \%$. FTIR spectrum of raw chitosan showed the following peaks; $3263 \mathrm{~cm}^{-1}, 3109.25 \mathrm{~cm}^{-1}, 1627 \mathrm{~cm}^{-1}$ and $2854 \mathrm{~cm}^{-1}$ denoting $-\mathrm{NH}_{2} /-\mathrm{NH}^{2}$ asymmetric stretching, $-\mathrm{OH}$ stretching, $-\mathrm{C}=\mathrm{O}$ stretching and $-\mathrm{CH}$ group showing that binding process for both metal ions onto chitosan bands at $3109.25 \mathrm{~cm}^{-1}$ and $2854 \mathrm{~cm}^{-1}$ in the spectrum. The spectra indicated $-\mathrm{NH}$ group was involved in the binding process due to substantial changes in absorption intensity of $-\mathrm{NH}$ stretching after adsorption and peak $1627 \mathrm{~cm}^{-1}$ assigned to $\mathrm{C}=\mathrm{O}$ occurred before the binding process. The two peaks in the $2800-2900 \mathrm{~cm}^{-1}$ region was observed in $\mathrm{Pb}^{2+}$ ion which disappear in the $\mathrm{Ni}^{2+}$ ion laden spectrum, the spectrum for $\mathrm{Ni}^{2+}$ ion has only one peak observed in this region while the $\mathrm{Pb}^{2+}$ ion has two and in the finger print region, 600-1000 $\mathrm{cm}^{-1}$, the spectra of $\mathrm{Ni}^{2+}$ ion and $\mathrm{Pb}^{2+}$ exhibited two and one peaks respectively. This supported the higher sorption capacity of $\mathrm{Pb}^{2+}$ ion over $\mathrm{Ni}^{2+}$ ion. The data were evaluated using Langmuir, Frieundlich and Temkin isotherms, the data complied with Frieundlich isotherm with high $\mathrm{R}^{2}$ values 0.984 and 0.971 for both metal ions while Temkin isotherm shows high $\mathrm{R}^{2}$ values 0.991 and 0.981 for both $\mathrm{Pb}^{2+}$ and $\mathrm{Ni}^{2+}$ ions respectively.
\end{abstract}

Keywords: Adsorption, pH, Chitosan, Heavy Metals, Snail Shells

\section{Introduction}

With the growth of industry, there has been a drastical increase in the discharge of industrial waste to the environment, chiefly soil and water, which has led to the accumulation of heavy metals, especially in urban areas. The indiscriminate release of heavy metals into the soil and waters is a major health concern worldwide, as they cannot be broken down to non-toxic forms and therefore have long-lasting effects on the ecosystem [1]. Likewise, the heavy metals present in this wastewater are persistent and non-degradable in nature. Moreover, they are soluble in aquatic environment and thus can be easily absorbed by living cells. Thus, by entering the food chain, they can be bioaccumulated and biomagnified in higher trophic levels also. The heavy metals, if absorbed above the permissible labels, could lead to serious health disorders. These heavy metals are widely generated as a wastewater or waste product in the industries like textiles, leather, paper, 
plastics, electroplating, cement, metal processing, wood preservatives, paints, pigments and steel fabricating industries during production which are not been treated or check the pollutant load before discharge to waterways and open lands [2]. These industries discharge large quantities of toxic wastes and the untreated effluents from these industries causes environmental and industrial pollution [3]. In light of the facts, treatment of heavy metals containing industrial effluent becomes quite necessary before being discharged into the environment. A wide range of physical and chemical processes are available for the removal of these metals from waste waters, such as precipitation, ultrafiltration, adsorption, ion-exchange, reverse osmosis, oxidation, ozonation, coagulation, flocculation and membrane filtration processes [4]. But most of these techniques become ineffective when the concentrations of heavy metals are less than $100 \mathrm{mg} / \mathrm{L}$ [5]. These methods are not very effective, are costly and require high energy input. They are associated with generation of toxic sludge, disposal of which renders it expensive and non-ecofriendly in nature and in the recent past, number of approaches has been investigated for safe and economical treatment of heavy metal laden wastewater. Adsorption has emerged out to be better alternative treatment methods and offering a wide advantage over other conventional processes. It is said to be effective and economical because of its relatively low cost [6]. Also low residual generation, ease of heavy metal removal and possibility for the reuse of the adsorbent makes adsorption an economical and favorable technology for heavy metal removal from wastewater.

However, many reports have been published on the lowcost adsorbents for heavy metals removal from aqueous solutions [7, 8, 9, 10], which has been found to be economically appealing for the removal of toxic metals from wastewater by choosing a perfect adsorbents under optimum operating conditions $[11,12]$ and in recent time, chitosan has been used for adsorption of heavy metals due to the attribution of exposed free amino groups, which chelates five to six times greater than chitin [13] and also possession of its wide excellent properties such as abundance, non-toxicity, biodegradability, hydrophyllicity and adsorption property [14]. Hence the objective of this work is to investigate effect of chitosan powder (size $<80$ micrometer) prepared from snail shells to remove $\mathrm{Pb}^{2+}$ ion and $\mathrm{Ni}^{2+}$ ions from wastewater, characterization of the used chitosan using Fourier Transform Infrared Spectroscopy (FTIR) and its adsorption isotherm model.

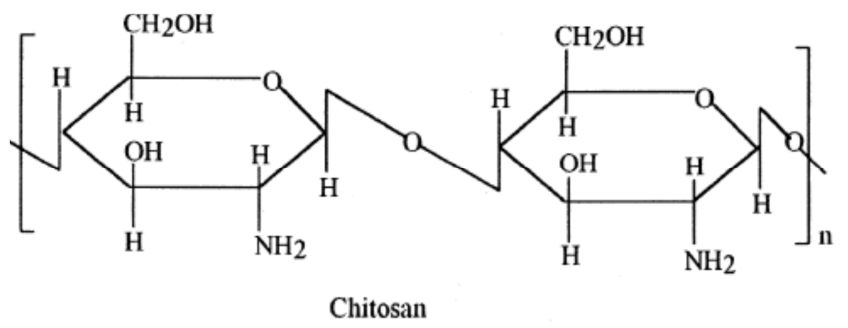

Figure 1. Structure of chitosan.
Chitosan is a unique basic polysaccharide and partially deacetylated polymer of glucosamine obtained after alkaline deacetylation of the chitin $[15,16,17]$. It consists of mainly of $\beta$ - (1-4-2- acetamido-2-deoxy-D-glucose) units and is the second most abundant biopolymer on earth after cellulose, widely distributed in crustacean shells and cell walls of fungus [16, 17, 18 and 19]. Chitosan is soluble in dilute acids and solubilisation occurs by the protonation of the $-\mathrm{NH}_{2}$ function on the $\mathrm{C}-2$ position of the D-glucosamine repeat unit, where by the polysaccharide is converted to a polyelectrolyte in acidic media. Chitosan are widely used for waste water treatments of polymers experimentally proven that decrease the chemical oxygen demand, total nitrogen and destroy the microbial population [20]. The high porosity of this natural polymer results in novel binding properties for metal ion such as cadmium, copper, lead, nickel uranyl, mercury and chromium etc., [21]. Water purification plants throughout the world use chitosan to remove oil, grease, heavy metals, and the fine particulate matter that cause turbidity in wastewater streams [16]. However, with the use of synthetic polymer; the low metallic strength, low thermal, mechanical stability and flexibility behavior of chitosan can be increase [22] and can also help chitosan to be modified physically and chemically [23, 24, 25]. It has been used widely as an adsorbent for transition metal ions and organic species because the amino $\left(-\mathrm{NH}_{2}\right)$ and hydroxyl $(-\mathrm{OH})$ groups on chitosan chains can serve as the coordination and reaction sites [26, 27]. It is also reported that chitosan has the highest chelating ability in comparison to other natural polymers obtained from seafood wastes and natural substances like bark, activated sludge and the synthetic polymer poly (4-aminostyrene) which is used in commercial chelating ion-exchange resins [28, 29].

\section{Materials and Methods}

\subsection{Materials}

All chemicals used in the study were of analytical grade obtained from Chemistry Department, Federal University of Technology Akure, Ondo State, Nigeria. Aqueous solutions of lead and nickel were prepared from lead nitrate and nickel sulphate respectively. Subsequent concentrations needed for the experiments were prepared by diluting the stock solutions to desired concentrations with de-ionized water. De-ionized water was used throughout the study and all glassware and other containers were thoroughly cleaned by soaking in detergent followed by soaking in $10 \%$ Nitric acid for $48 \mathrm{hrs}$ and finally rinsed with de-ionized water several times prior to use.

\subsection{Preparation of Chitosan}

The chitosan used were prepared based on the method proposed by Wan Ngah and Fatinathan [19, 30]. Chitosan used was synthesized from snail shells purchased from a local market in Akure South Local Government Area, Ondo State, Nigeria. The shells were washed, dried and pulverized into fine powder using mechanical grinding machine, the 
sample was deproteinised using $1.2 \mathrm{M} \mathrm{NaOH}$, boiled at $70^{\circ} \mathrm{C}$ for one hour, washed severally with de-ionized water, then obtained sample was demineralized using $0.7 \mathrm{M} \mathrm{HCl}$, boiled at $70^{\circ} \mathrm{C}$ for $15 \mathrm{mins}$, wash severally with de-ionized water. The resulting sample was deacetylated using 50\% $\mathrm{NaOH}$, boiled at $100^{\circ} \mathrm{C}$ for $3 \mathrm{hrs}$, washed and filtered repeatedly until the filtrate became neutral, oven-dried, cooled and sieved to obtain 280-300 micrometre mesh size.

\subsection{Methods}

Adsorption experiments were conducted in Erlenmeyer flasks with ground-glass stoppers. $30 \mathrm{ml}$ of each metal ion solution were transferred to different $100 \mathrm{ml}$ flasks together with $0.3 \mathrm{~g}$ of snail shell derived chitosan, and placed in a water bath shaker maintained at $25^{\circ} \mathrm{C}$. Accurately weighed $0.3 \mathrm{~g}$ of chitosan was added to each of the beaker, The mixtures were stirred continuously and allowed to stand for 6hrs, then the mixtures were then filtered using Whattman number 4 filter paper and the filtrates taken for metal ion analysis using Atomic Absorption Spectrometer (Model: buck scientific VPG210). The extent of removal of the two metals was investigated separately on the effect of adsorbent dose, effect of temperature, effect of $\mathrm{pH}$ of the solution, effect of contact time in shaking the adsorbent metal solution mixture and effect of metals ion concentration by varying needed parameters and keeping other parameters constant [31]. The $\mathrm{pH}$ (Mudder 0.01 readout accuracy digital pocket pen type, Backlit LCD. 0.00$14.00 \mathrm{pH}$ meter) of each solution was adjusted to different values with either $\mathrm{NaOH}$ or $\mathrm{HCl}$ in duplicate.

\subsection{Factors Influencing Adsorption Process}

\subsubsection{Effect of Adsorbent Dose}

The effect of adsorbent weight on the adsorption was studied by using $30 \mathrm{ml}$ of each metal ion solution were transferred to different $100 \mathrm{ml}$ flasks together with $0.3 \mathrm{~g}$ of snail shell derived chitosan, and placed in a water bath shaker maintained at $298 \mathrm{~K}$ for suitable time with different weigh of adsorption dose $(0.25,0.5,0.75 .1 .00,1.25,1.50 \mathrm{~g})$.

\subsubsection{Effect of Temperature}

Adsorption process was performed in the same manner as mentioned in the above paragraph at temperature 305, 315, $325,335,345$ and $355 \mathrm{~K}$ to estimate the thermodynamic behavior of adsorption process, this depends if the adsorption decreases with increasing temperature then the process is exothermic and vice versa.

\subsubsection{Effect of Contact Time}

Effect of contact time on adsorption was studied by using $30 \mathrm{ml}$ of each metal ion solution were transferred to different $100 \mathrm{ml}$ flasks together with $0.3 \mathrm{~g}$ of snail shell derived chitosan, and placed in a water bath shaker maintained at $298 \mathrm{~K}$ for suitable time with a time range of 5, 15, 30, 60, 90, 120, 150, 180, 240, 300 and 360 mins.

\subsubsection{Effect of $\mathrm{pH}$}

The effect of adsorbent weight on the adsorption was studied by using $30 \mathrm{ml}$ of each metal ion solution were transferred to different $100 \mathrm{ml}$ flasks together with $0.3 \mathrm{~g}$ of snail shell derived chitosan, and placed in a water bath shaker maintained at $298 \mathrm{~K}$ for suitable time with different $\mathrm{pH}$ media. $\mathrm{NaOH}(0.1 \mathrm{~N})$ and $(0.1 \mathrm{~N}) \mathrm{HCL}$ were used to adjust the $\mathrm{pH} 1.0,2.0,3.0,4.0,5.0,6.0,7.0,8.0,9.0$ and the concentration of the adsorbent was measured by UV-visible spectrophotometer.

\subsubsection{Effect of Metals Ion Concentration}

Adsorption process was performed in the same manner as mentioned in the above paragraph at with initial metal ion concentrations ranging from 100, 200, 300, 400 and $500 \mathrm{mg} / \mathrm{l}$ with a fixed adsorbent dose of $0.3 \mathrm{~g}$ at the optimum $\mathrm{pH}$ and contact time.

The removal efficiency $(E)$ was calculated using;

$$
E(\%)=\left[\left(\mathrm{Co}-\mathrm{C}_{1}\right) / \mathrm{Co}\right] \times 100
$$

Where $\mathrm{C}_{0}$ and $\mathrm{C}_{1}$ denote the initial concentration and final residual concentration of metal ion in $\mathrm{mg} / \mathrm{l}$ respectively.

\section{Results and Discussion}

\subsection{FTIR Analysis of the Biosorbent and Biosorbent-Metals}

Chitosan as a biomaterial that contains several active binding sites. The active groups of the derived chitosan powder before and after metal ion removal were analysed using FTIR spectrometer. Figure 2. Shows the spectrum of raw chitosan while Figure 3 and Figure 4 show the spectra of $\mathrm{Pb}^{2+}$ ion laden chitosan and $\mathrm{Ni}^{2+}$ ion laden chitosan respectively. FTIR spectroscopy provides information through bonding properties, frequencies and intensities, and can therefore be used to identify species and predict chemical processes involved. FTIR spectrum of raw chitosan in Figure 2 shown a broad absorption band in the range 3000 to $3500 \mathrm{~cm}^{-1}$ which is attributed to $\mathrm{O}-\mathrm{H}$ stretching vibrations and the $3263 \mathrm{~cm}^{-1}$ to vibration of $\mathrm{NH}$. The stretching vibrations of methylene $\mathrm{C}-\mathrm{H}$ at $2854 \mathrm{~cm}^{-1}$, absorption peak at $1558 \mathrm{~cm}^{-1}$ correspond to the $\mathrm{NH}_{2}$. The amide II band is used as the characteristic band of $\mathrm{N}$ acetylation [32]. The spectra of raw chitosan showed the different vibration that occurs after deacetylation process, which was not the emergence of vibration $\mathrm{C}=\mathrm{O}$ at $1627 \mathrm{~cm}^{-1}$ region which indicates the vibration of $\mathrm{C}=\mathrm{O}$ has been reduced on chitosan as well as the emergence of absorption at $894 \mathrm{~cm}^{-1}$ on chitosan which was the vibration of $\mathrm{NH}_{2}$. Raw Chitosan showed no amide band, but hydroxyl and, amino bands at the ranged spectra up to $3500 \mathrm{~cm}$. In terms of chemical properties, raw chitosan is more applicable, due to its molecular structure as a high molecular weight polymer, being a linear polyamine whose amino groups are readily available for chemical reactions and salt formation with acids.

FTIR analysis of $\mathrm{Pb}^{2+}$ laden Chitosan and $\mathrm{Ni}^{2+}$ laden Chitosan.

The spectrum for $\mathrm{Pb}^{2+}$ ion laden Chitosan in figure 3 shown the presence of the following functional groups $\mathrm{O}-\mathrm{H}$ stretching 
vibrations (3466), CC-H stretching vibrations (2921, 2853), C$\mathrm{H}$ first stretch overtone $(1734 ; 1643), \mathrm{CH}_{2}$ bending (1456; 1401), C-O valence vibration (1036). While the spectrum for $\mathrm{Ni}^{2+}$ ion laden Chitosan shown in Figure 4 shows the presence of $\mathrm{O}-\mathrm{H}$ stretching vibrations $(3344.5,2360.6)$, (2340.1), (1636.4), $\mathrm{C}=\mathrm{O}$ and $\mathrm{COOH}$ overtones $(668.1,620.1)$. The spectra indicated that $-\mathrm{NH}$ group was involved in the binding process because there were substantial changes in the absorption intensity of the $-\mathrm{NH}$ stretching after adsorption. Vibration shift was observed for the possible O-H, N-H absorption peaks. This could be possibly attributed to the interaction of the functional group with metal ions. The two peaks in the $2800-2900 \mathrm{~cm}^{\square}$ region observed in $\mathrm{Pb}^{2+}$ ion disappear in the $\mathrm{Ni}^{2+}$ ion laden spectrum. Another spectral shift is observed in the $1600-1700 \mathrm{~cm}^{1}$ region for the $\mathrm{Pb}^{2+}$ ion laden spectrum. The spectrum for $\mathrm{Ni}^{2+}$ ion has only one peak observed in this region while the $\mathrm{Pb}^{2+}$ ion has two. In the finger print region, $600-1000 \mathrm{~cm}^{1}$, the spectra of $\mathrm{Ni}^{2+}$ ion and $\mathrm{Pb}^{2+}$ exhibited two and one peaks respectively. This supported the higher sorption capacity of $\mathrm{Pb}^{2+}$ ion over $\mathrm{Ni}^{2+}$ ion [33]. The information observed from FTIR spectral data has shown that the $-\mathrm{OH}$ and possibly the $-\mathrm{NH} 2$ groups were present on the surface of chitosan and may have been responsible for the uptake of $\mathrm{Pb}^{2+}$ ions on the chitosan These functional groups are known to act as very active legends and therefore, tend to bind readily with metals ions.
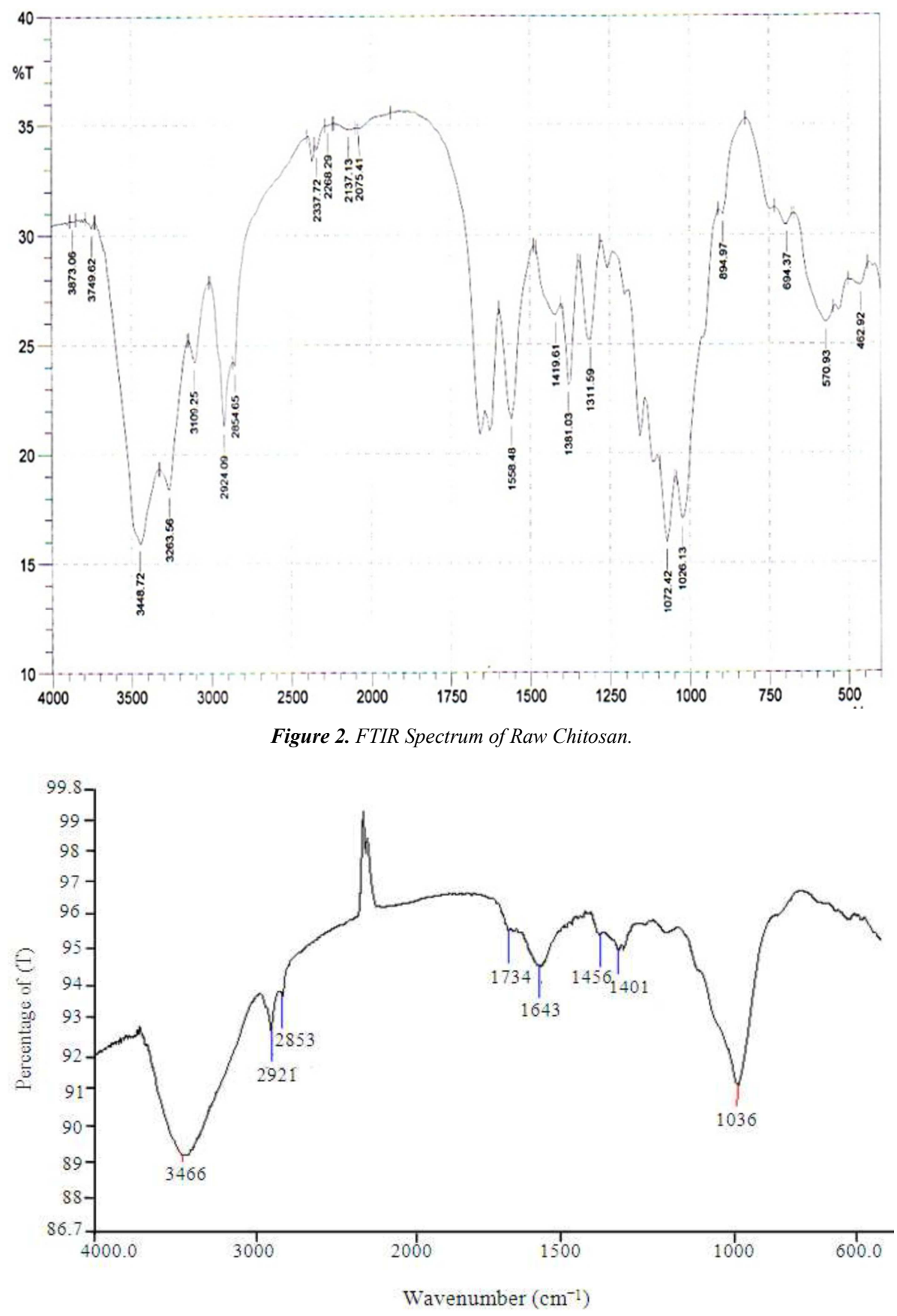

Figure 3. FTIR Spectrum of $\mathrm{Pb}^{2+}$ ion laden Chitosan. 


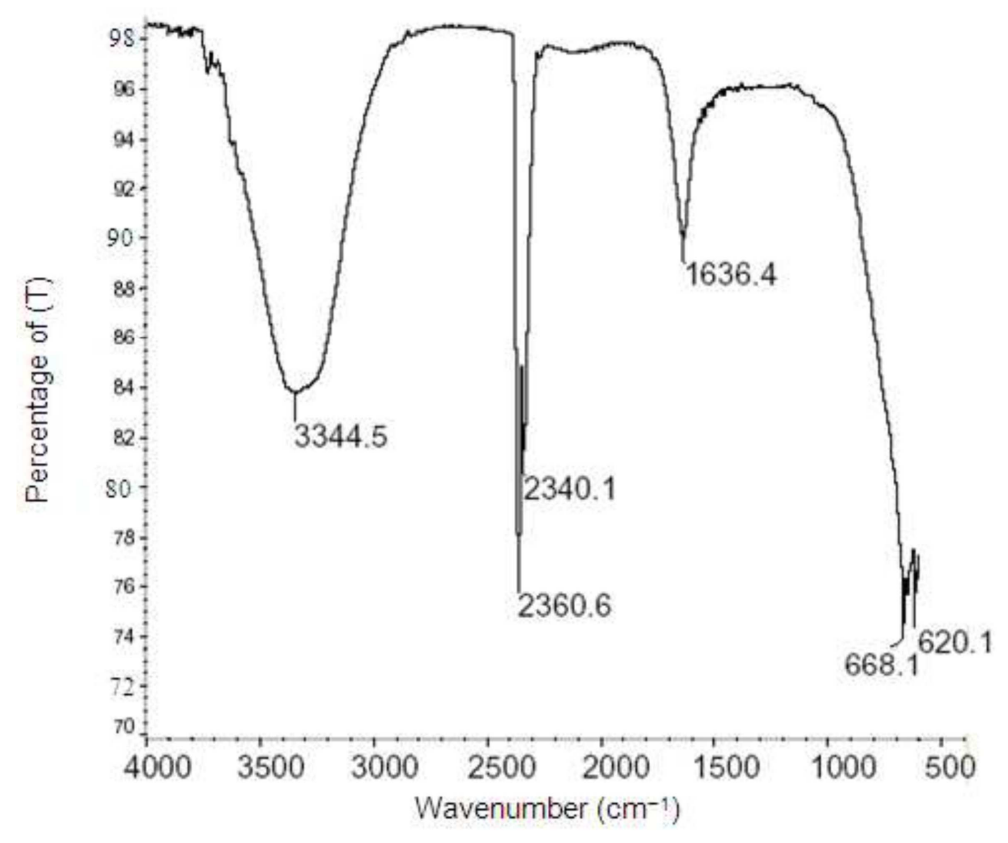

Figure 4. FTIR Spectrum of $\mathrm{Ni}^{2+}$ laden Chitosan.

\subsection{Result of Analysis on Factor Influencing Adsorption Process}

\subsubsection{Result of Analysis on Effect of Adsorbent Dose on the Adsorption of $\mathrm{Pb}^{2+}$ and $\mathrm{Ni}^{2+}$ (II) Ions}

Adsorbent provides binding sites for the sorption of metal ions, and hence its concentration strongly affects the sorption of metal ions from the solution [34]. The amount of adsorbent used for the treatment studies is an important parameter, which determines the potential of adsorbent to remove metal ions at a given initial concentration [35]. The study effect of adsorbent dose on metal adsorption has shown that adsorption had increased for both the metals with increase in amount of chitosan derived from snail shell. The effect of the amount of adsorbent for the removal of $\mathrm{Pb}^{2+}$ and $\mathrm{Ni}^{2+}$ ions was depicted in the Figure 5. It was shown that the removal of $\mathrm{Ni}^{2+}$ ions increases with an increase in the amount of adsorbent until record the highest value then decreased while for $\mathrm{Pb}^{2+}$ ion there is no dramatically increase in adsorption rate as the adsorbent dosage increases.

The amount of adsorbent dose varied ranging from $0.25 \mathrm{~g}$ to $1.50 \mathrm{~g}$ and For $\mathrm{Pb}^{2+}$ ion, minimum percentage removal was $99.81 \%$ for the dose of $0.25 \mathrm{~g}$ to maximum value of $99.93 \%$ for the dose of $0.5 \mathrm{~g}$, therefore for $\mathrm{Pb}^{2+}$ ion it can be observed that removal efficiency of the adsorbent generally improved with increasing dose due to availability of more binding sites in the surface of the adsorbent as the dosage increases [22, 36, 37, 38]. This is expected due to the fact that the higher dose of adsorbents in the solution, the greater availability of exchangeable sites for the ions [39]. It showed no further increase in adsorption after a certain amount of adsorbent was added $(1.00-1.50 \mathrm{~g})$. This suggests that after a certain dose of adsorbent, the maximum adsorption sets in and hence the amount of metal ions bound to the adsorbent and the amount of free ions remain constant even with further addition of adsorbent dose [40]. Whereas for $\mathrm{Ni}^{2+}$ ion, minimum percentage removal was $40.61 \%$ for the dose of $1.50 \mathrm{~g}$ to maximum value of $70.58 \%$ for the dose of $0.75 \mathrm{~g}$. This shows that there was a dramatically increase in the rate of adsorption of $\mathrm{Ni}^{2+}$ ion from $0.25-0.75 \mathrm{~g}$ of the adsorbent dose due the active sites on an adsorbent get deprotonated [13, 41] causing an increase in the rate of adsorption dose and also decreases from $0.75-1.50 \mathrm{~g}$ of the adsorbent dose due to the fact that the active site on the adsorbent dose get protonated as the adsorbent dose increases, the adsorbent is positively charged and hence offers repulsive force to approaching the metal ions, therefore leading to a decrease in the adsorption of $\mathrm{Ni}^{2+}$ ion at higher adsorbent dose [42]. However, the percentage adsorption of metal ions was higher for $\mathrm{Pb}^{2+}$ ion as compared to the $\mathrm{Ni}^{2+}$ ion and likewise this result showed that the adsorbent dose chitosan was efficient for maximum removal of $\mathrm{Pb}^{2+}$ and $\mathrm{Ni}^{2+}$ ions.

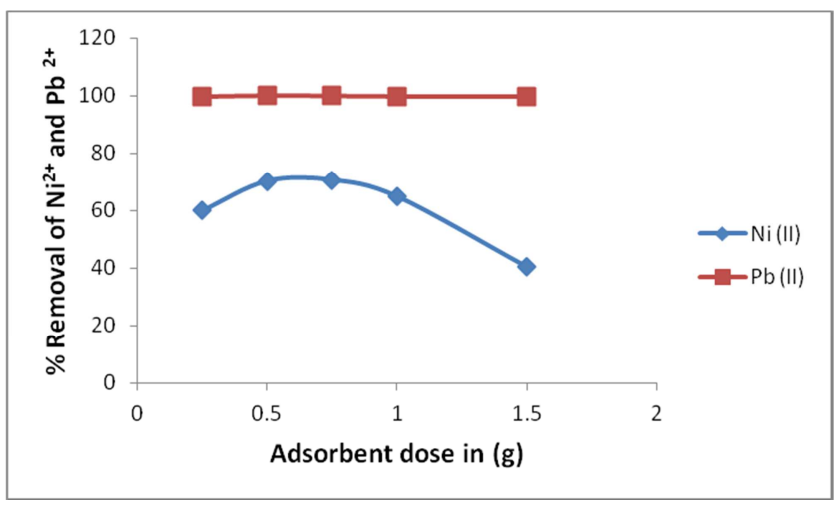

Figure 5. Effect of adsorbent dose on the adsorption of $\mathrm{Pb}^{2+}$ and $\mathrm{Ni}^{2+}$ ions.

\subsubsection{Result of Analysis on Effect of Temperature on the Adsorption of $\mathrm{Pb}^{2+}$ and $\mathrm{Ni}^{2+}$ Ions}

Temperature change affects the stability of the metal ion species initially placed in solution. Increase in temperature 
increases the rate of adsorbate diffusion across external pore at the adsorbate particles because liquid viscosity decreases as temperature increases [43]. It can be seen in Figure 6 that for $\mathrm{Pb}^{2+}$ ion there is increase in the adsorption rate as the temperature increases from $305-325 \mathrm{~K}$ and decreases as the temperature increases from $325-355 \mathrm{~K}$ and maximum adsorption was observed at $335 \mathrm{~K}$ for $\mathrm{Pb}^{2+}$ ion showing $87 \%$ removal and at over $335 \mathrm{~K}$ adsorption decreased to $45 \%$ removal of the $\mathrm{Pb}^{2+}$ ion, as seen in Figure 6 below, with an increase in temperature, adsorption capacity decreases due to fact that as decrease in activity surface brings about adsorption between $\mathrm{Pb}^{2+}$ ion and chitosan adsorbent leading to an exothermic process [44]. Also, with increasing temperature, the forces of attraction between the chitosan surface and $\mathrm{Pb}^{2+}$ ion get loosen and weakened and bring about weak binding interaction between the active sites metal ion which set in decrease in sorption rate to support physiosorption which is exothermic process [45]. Likewise for $\mathrm{Ni}^{2+}$ ion, there is increase in the adsorption rate as the temperature increases from $305-355 \mathrm{~K}$ and maximum adsorption occur at $355 \mathrm{~K}$ showing $80 \%$ removal of $\mathrm{Ni}^{2+}$ ion which suggesting that adsorption between $\mathrm{Ni}^{2+}$ ion and chitosan was an endothermic process, the increase in temperature not only increases the rate of diffusion of the metal ions present but also increases the rate of complexation with the functional groups present in the adsorbent [46]. Therefore $\mathrm{Pb}^{2+}$ has $87 \%$ removal with an exothermic process and $\mathrm{Ni}^{2+}$ has $80 \%$ removal with an endothermic process.

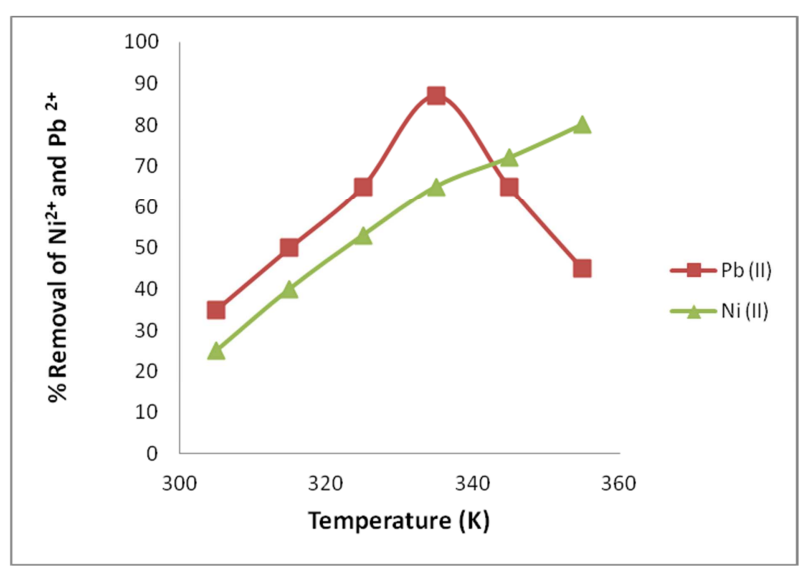

Figure 6. Effect of Temperature on the adsorption of $\mathrm{Pb}^{2+}$ and $\mathrm{Ni}^{2+}$ ions.

\subsubsection{Result of Analysis on Effect of Contact Time on the Adsorption of $\mathrm{Pb}^{2+}$ and $\mathrm{Ni}^{2+}$ Ions}

In batch adsorption experiments, the determination of the optimum contact time required to achieve the highest removal of metal ions is one of the key factors usually assessed. Equilibrium time is one of the important parameters for selecting a wastewater treatment system [47]. Effect of contact time on adsorption was studied and the results are shown in Figure 7. This result indicated that metal ions removal was increased with an increase in contact time before equilibrium was reached [15]. Other parameters such as dose of adsorbent and $\mathrm{pH}$ of solution were kept constant. Increase in removal efficiency with increase in time of contact can be attributed to the fact that more time becomes available for metal ions to make an attractive complex with chitosan [48]. Likewise, the rate of percentage metal removal is higher in the beginning due to a larger surface area of the adsorbent being available for the adsorption of the metals. The metal uptake by the sorbent surface will be rapid initially, and then slow down as the active site get adsorbed by the heavy metals remaining in solution [49].

From the obtained result, it was shown that the removal of metal ions increased as contact time increases from $5-120$ mins for both $\mathrm{Pb}^{2+}$ and $\mathrm{Ni}^{2+}$ ions while there is no appreciable change in the adsorption rate for both $\mathrm{Pb}^{2+}$ and $\mathrm{Ni}^{2+}$ ions as they tend to attained equilibrium at $180-360$ mins contact time with $\mathrm{Pb}^{2+}$ recording $99.83 \%$ removal and $\mathrm{Ni}^{2+}$ ion showing a recording $70.37 \%$ removal. This plots indicated that the remaining concentration of metal ions becomes asymptotic to the time axis such that there is no appreciable change in the remaining metal ion concentration after 180 mins for both metal ions. This time (180mins) represent the equilibrium time at which an equilibrium metal ion concentration $\left(\mathrm{C}_{\mathrm{e}}\right)$ is presume to have been attained for both $\mathrm{Pb}^{2+}$ and $\mathrm{Ni}^{2+}$ ions. It is evident that the adsorption of the two metal ions unto chitosan follows two phases, a linear phase of adsorption and then an almost flat plateau section. This may be attributed to the instantaneous utilization of the most readily available adsorbing sites on the adsorbent surface, which go in line and the same with work published by [50].

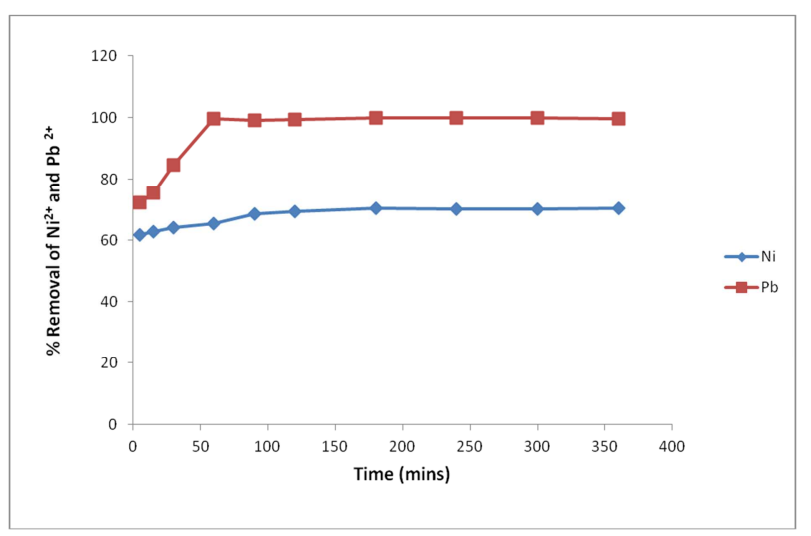

Figure 7. Contact Time Studies of the adsorption of $\mathrm{Pb}^{2+}$ and $\mathrm{Ni}^{2+}$ ions.

\subsubsection{Result of Analysis on Effect of $p H$ on the Adsorption of $\mathrm{Pb}^{2+}$ and $\mathrm{Ni}^{2+}$ Ions}

The solution $\mathrm{pH}$ is one of the parameters having considerable influence on the adsorption of metal ions, because the surfaces charge density of the adsorbent and the charge of the metallic species present on the $\mathrm{pH}$ [51]. Also $\mathrm{pH}$ can affects concentration of the counter ions on the functional groups of the adsorbent, surface charge of the adsorbent, equilibrium of the system, metal chemistry of solution, and the degree of ionization of the of the adsorbate during reaction [52, $53,54]$. The adsorption of $\mathrm{Pb}^{2+}$ and $\mathrm{Ni}^{2+}$ ions on snail shell derived chitosan was studied over a $\mathrm{pH}$ range $1.0-9.0$ by using a fixed concentration at $298 \mathrm{~K}$. The role of hydrogen ion concentration was examined in solutions at different $\mathrm{pH}$. From Figure 8 , it can be explained by the following facts that at 
lower $\mathrm{pH}$ values, $\mathrm{H}^{+}$in the solution will compete strongly with heavy metals ion for the active sites due to the fact that the adsorbent is positively charged and hence offers repulsive force to approaching the metal ions therefore, it reduces heavy metal ion binding on the adsorbent surface [55]. When $\mathrm{pH}$ increases, the electrostatic repulsion between heavy metals ions and surface sites and the competing effect of $\mathrm{H}^{+}$decrease and consequently the heavy metals ion adsorption increases [56]. The result in Figure 8 showed an increase in adsorption with increasing $\mathrm{pH}$ of solution for both metals ions. For $\mathrm{Pb}^{2+}$ ion showing the removal efficiency from $55.48 \%$ to $82.1 \%$ over a $\mathrm{pH}$ range of 1.0 - 5.0 and then decline at higher $\mathrm{pH} 5.0$ 9.0 showing a decrease in the removal efficiency $82.1 \%$ to $42.68 \%$ and likewise for $\mathrm{Ni}^{2+}$ ion, showing an increase in the removal efficiency from $9.12 \%$ to $68.26 \%$ over a $\mathrm{pH}$ range of $1.0-7.0$ and drastically decrease at higher $\mathrm{pH} 7.0-9.0$ showing a decrease in the removal efficiency from $68.28 \%$ to $58.5 \%$. This result explain that $\mathrm{Pb}^{2+}$ ion show that maximum removal were obtained at $\mathrm{pH} 5$ with little significance to $\mathrm{pH} 4$ while $\mathrm{Ni}^{2+}$ ion show that maximum removal were obtained at $\mathrm{pH}$ 7. Beyond this optimum $\mathrm{pH}$, the results showed a decrease in adsorption for both metal ions due to formation precipitates or metal hydroxides as $\mathrm{Pb}(\mathrm{OH})_{2}$ and $\mathrm{Ni}(\mathrm{OH})_{2}$. Hence $82.1 \%$ removal of $\mathrm{Pb}^{2+}$ ion was achieved even at a low $\mathrm{pH}$ of 5 because of the low concentration of $\mathrm{Pb}^{2+}$ ion present in the wastewater. The increase in percentage removal of the metal ions may be explained by the fact that at higher $\mathrm{pH}$ the adsorbent surface is deprotonated and negatively charge; hence attraction between the positively metal cations occurred [57]. Likewise Increases in metal removal with increase $\mathrm{pH}$ can be explained on the basis of a decrease in competition between proton and metal cations for same functional groups and by decrease in positive surface charge, which results in a lower electrostatic repulsion between surface and metal ions and brings about decrease in adsorption at higher $\mathrm{pH}$ is due to formation of soluble hydroxyl complexes [15, 58] These Similar trend was observed with the adsorption of lead and Nickel from aqueous solution by chitosan $[59,60,61]$.

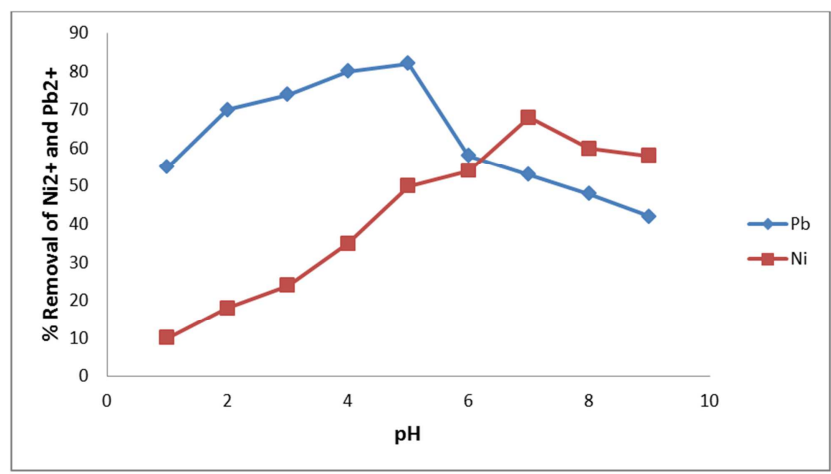

Figure 8. pH Profile Studies of the adsorption of $\mathrm{Pb}^{2+}$ and $\mathrm{Ni}^{2+}$.

\subsubsection{Result of Analysis on Effect of Initial Metal Ion Concentration on the Adsorption of $\mathrm{Pb}^{2+}$ and $\mathrm{Ni}^{2+}$ Ions}

Initial ion concentration has a significant effect on the adsorption of heavy metals ions from wastewater through ability of surface functional groups to bind metal ions and provide a driving force to overcome the mass transfer resistance of metal between the aqueous and solid phases [62, 63]. As initial metal ion concentration increases, there is an increase in the amount of metal ions bound but the percentage quantity adsorbed decreases [64, 65]. From the study, it was shown that effect of initial metal ion concentration $\left(\mathrm{C}_{0}\right)$ on the adsorption behaviour of $\mathrm{Pb}^{2+}$ and $\mathrm{Ni}^{2+}$ metal ions samples, ranging from 100 to $500 \mathrm{mg} / 1$ with a fixed adsorbent dose of $0.3 \mathrm{~g}$ at the optimum $\mathrm{pH}$ and contact time. Figure 9 showed that $\mathrm{Pb}^{2+}$ has optimum adsorption at $75 \mathrm{mg} / \mathrm{L}$ with $7.48 \mathrm{mg} / \mathrm{g}$ metal removal corresponding to $99.97 \%$ metal bound; $\mathrm{Ni}^{2+}$ showed optimum adsorption at $10 \mathrm{mg} / \mathrm{L}$ with $0.85 \mathrm{mg} / \mathrm{g}$ metal removal corresponding to $84.74 \%$ metal bound. The adsorbed metal ion for $\mathrm{Pb}^{2+}$ and $\mathrm{Ni}^{2+}$ ionsvalues increased with increase in initial ion concentration $\left(\mathrm{C}_{0}\right)$, this increase is probably due to a high driving force for mass transfer, therefore when the concentration of metal ions in solution was higher, the adsorption capacity also increases [66].



Figure 9. Initial Metal ion Concentration Study of the adsorption of $\mathrm{Pb}^{2+}$ and $\mathrm{Ni}^{2+}$ ions.

\section{Adsorption Model}

\subsection{Adsorption Isotherm}

The adsorption isotherms are one of the most useful data to understand the mechanism of the adsorption and the characteristics of isotherms are needed before the interpretation of the kinetics of the adsorption process. It is also to examine the relationship between sorbed $\left(q_{e}\right)$ and aqueous concentration $C_{e}$ at equilibrium, sorption isotherm models are widely employed for fitting the data, of which the Langmuir and Freundlich equations are most widely used to describe the equilibrium sorption of metal ions [59]. Several equilibrium data are usually verified using adsorption isotherms to study the nature of adsorption process. These include Langmuir, Freundlich and Temkin isotherm models.

\subsection{The Langmuir Isotherm}

The Langmuir isotherm model assumes a surface with homogeneous binding sites, equivalent sorption energies, and no interaction between sorbed species [67]. The Langmuir model assumes that the uptake of metal ions occurs on a 
homogenous surface by monolayer adsorption without any interaction between adsorbed ions [68]. In this model once a site is filled, no further sorption can take place at that site. As such, the surface will eventually reach a saturation point where the maximum adsorption of the surface will be achieved [69]. The Langmuir equation has been frequently used to give the sorption equilibrium. The Langmuir isotherm represents the equilibrium distribution of metal ions between the solid and liquid phases. To get the equilibrium data, initial metal concentrations were varied while the adsorbent mass in each sample was kept constant. The linearised Langmuir isotherm allows the calculation of adsorption capacities and Langmuir constant by the following equation:

$$
\frac{C_{e}}{q_{e}}=\frac{1}{q_{o} b}+\frac{C_{e}}{q_{o}}
$$

Where $\mathrm{C}_{\mathrm{e}}$ is the equilibrium concentration $(\mathrm{mg} / \mathrm{L}), \mathrm{q}_{\mathrm{e}}$ is the amount adsorbed at equilibrium; $\mathrm{q}_{\mathrm{o}}$ and $\mathrm{b}$ is Langmuir constants related to the adsorption capacity and energy respectively. The essential characteristic of the Langmuir isotherm may be expressed in terms of dimensionless separation parameter $\mathrm{R}_{\mathrm{L}}=1 /\left(1+\mathrm{b} \mathrm{C}_{0}\right)$, which is indicative of the isotherm shape that predicts whether an adsorption system is favourable or unfavourable [70], The adsorption process as a function of $R_{L}$ may be described as: Unfavorable when $\mathrm{R}_{\mathrm{L}}>1$; Linear when $\mathrm{R}_{\mathrm{L}}=1$; Favorable when $0<\mathrm{R}_{\mathrm{L}}$ $<1$; Irreversible when $\mathrm{R}_{\mathrm{L}}=0$. The plots of $\mathrm{C}_{\mathrm{e}} / \mathrm{q}_{\mathrm{e}}$ vs $\mathrm{C}_{\mathrm{e}}$ for both $\mathrm{Pb}^{2+}$ and $\mathrm{Ni}^{2+}$ ions were presented in Figure 10 and 11 respectively. $\mathrm{R}^{2}$ values of 0.752 for $\mathrm{Ni}^{2+}$ suggested that the Langmuir isotherm provided a fairly favourable model for the sorption process, whereas $\mathrm{Pb}^{2+}$ ion with $\mathrm{R}^{2}$ value of 0.125 indicated that the data did not fit into Langmuir Isotherm.

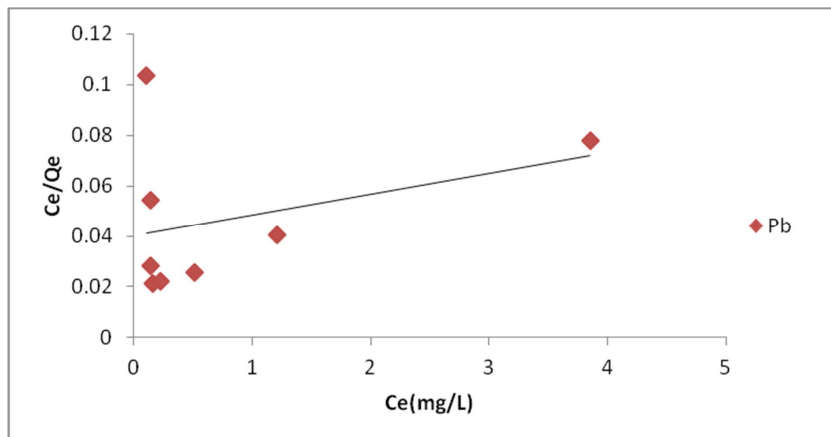

Figure 10. Plot of Langmuir Isotherm for $\mathrm{Pb}^{2+} \mathrm{Ion}$.

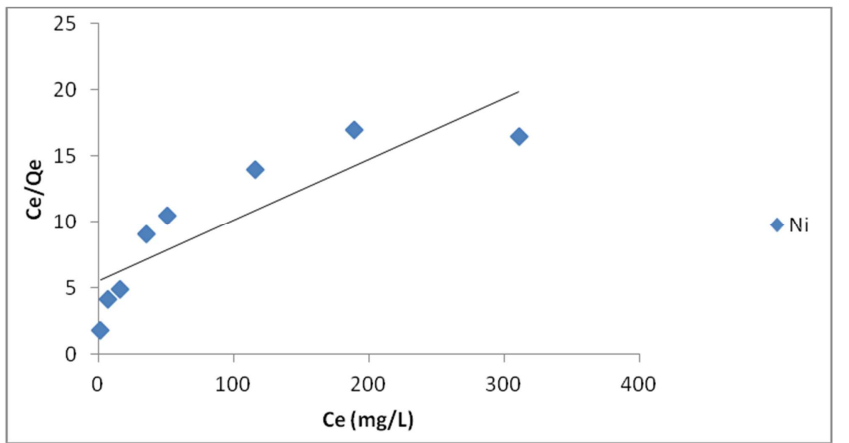

Figure 11. Plot of Langmuir Isotherm for $\mathrm{Ni}^{2+}$ Ion.

\subsection{The Freundlich Isotherm}

The Freundlich isotherm model applies to adsorption on heterogeneous surfaces with the interaction between adsorbed molecules, and the application of the Freundlich equation also suggests that sorption energy exponentially decreases on completion of the sorption centers of an adsorbent $[69,23]$. The Freundlich isotherm equation is used for the description of multilayer adsorption with the interaction between adsorbed molecules. The model predicts that the adsorbate concentration in the solution will be increasing. The non-linear form of Freundlich equation may be written as:

$$
\log \mathrm{q}_{\mathrm{e}}=\log \mathrm{K}_{\mathrm{F}}+1 / \mathrm{n}_{\mathrm{F}} \log \mathrm{C}_{\mathrm{e}}
$$

Where $\mathrm{C}_{\mathrm{e}}$ is the equilibrium concentration $(\mathrm{mg} / \mathrm{L}), \mathrm{q}_{\mathrm{e}}$ is the amount of metal adsorbed at equilibrium $(\mathrm{mg} / \mathrm{g}), \mathrm{K}_{\mathrm{F}}$ and $\mathrm{n}_{\mathrm{F}}$ are Freundlich constants; $\mathrm{n}_{\mathrm{F}}$ gives an indication of the favorability and $\mathrm{K}_{\mathrm{F}}$ the capacity of adsorbent. Figure 12 shows the plots of $\log \mathrm{q}_{\mathrm{e}}$ against $\log \mathrm{C}_{\mathrm{e}}$ for $\mathrm{Pb}^{2+}$ and $\mathrm{Ni}^{2+}$ ions. Then value indicates the degree of nonlinearity between solution concentration and adsorption as follows: if $\mathrm{n}=1$, then adsorption is linear; if $\mathrm{n}<1$, then adsorption is a chemical process; if $n>1$, then adsorption is a physical process [71]. The calculated Frieundlich constants as presented in Table 1 showed that the values of $n_{F}$ for both metal ions were greater than 1 indicating a favorable adsorption process (chemical process). The high correlation coefficient, $\mathrm{R}^{2}$ values proved that the data complied with Frieundlich isotherm. The results then indicated heterogenous system, better adsorption mechanism and formation of relatively stronger bond between the adsorbent and adsorbate. Patil et al., 2006 [72] submitted similar report using PAC and Babhul back for $\mathrm{Ni}^{2+}$ removal.

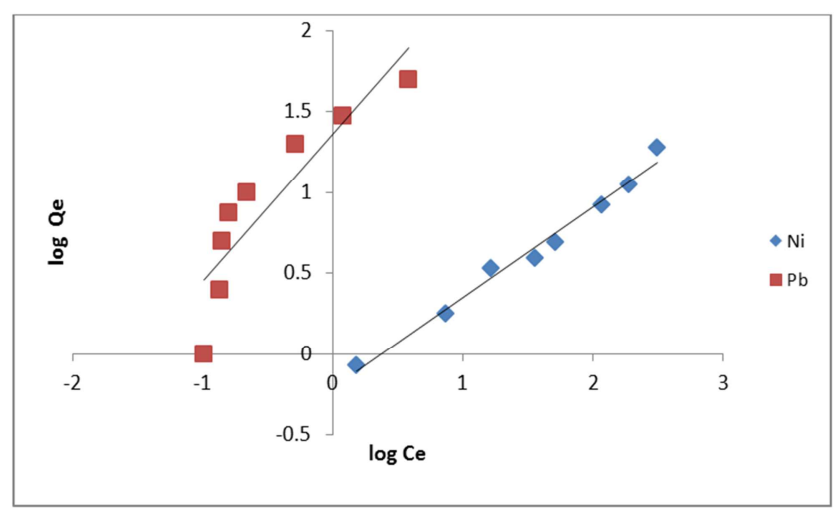

Figure 12. Plot of Freundlich Isotherm Model of $\mathrm{Pb}^{2+}$ and $\mathrm{Ni}^{2+}$ ions.

\subsection{The Temkin Isotherm}

The Temkin isotherm model [73] suggests an equal distribution of binding energies over a number of exchange sites on the surface. The Temkin isotherm in its linear form is given by the equation;

$$
\mathrm{q}_{\mathrm{e}}=\mathrm{B}_{\mathrm{T}} \log \mathrm{K}_{\mathrm{T}}+\mathrm{B}_{\mathrm{T}} \log \mathrm{C}_{\mathrm{e}}
$$

The magnitude of the Temkin parameters $B_{T}$ is related to 
the heat of adsorption and $\mathrm{K}_{\mathrm{T}}$ is equilibrium binding constant. Figure 13 shows the Temkin curves for metal ions adsorption, examination of the data showed that the Temkin isotherm provided a very good fit for both $\mathrm{Pb}^{2+}$ and $\mathrm{Ni}^{2+}$ ions with high correlation coefficient, $\mathrm{R}^{2}$ values of 0.736 and 0.991 for $\mathrm{Ni}^{2+}$ and $\mathrm{Pb}^{2+}$ ions respectively.

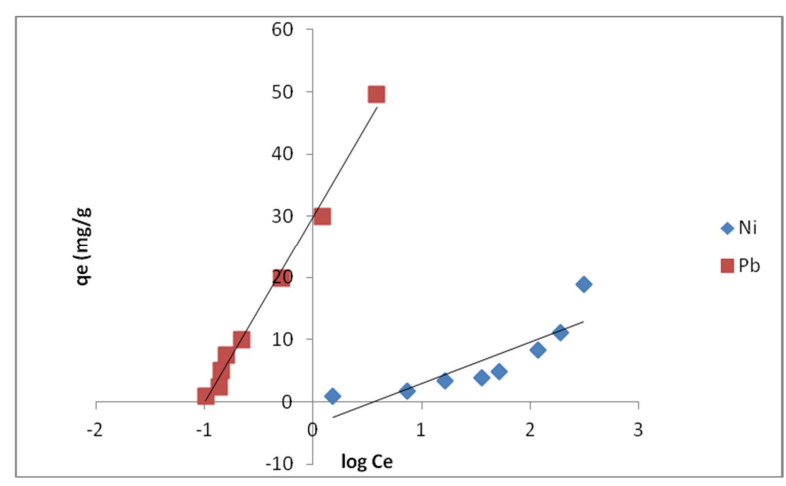

Figure 13. Lots of Temkin Isotherm of $\mathrm{Pb}^{2+}$ and $\mathrm{Ni}^{2+}$ ions.

Table 1. Sorption Isotherm Parameters for $\mathrm{Pb}^{2+}$ and $\mathrm{Ni}^{2+}$ ions.

\begin{tabular}{llll}
\hline Isotherm model & Parameters & Lead $\left(\mathbf{P b}^{2+}\right)$ & Nickel $\left(\mathbf{N i}^{2+}\right)$ \\
\hline Freundlich & $\mathrm{K}_{\mathrm{F}}$ & 22.845 & 0.612 \\
& $\mathrm{~N}_{\mathrm{F}}$ & 1.102 & 1.784 \\
& $\mathrm{R}^{2}$ & 0.7973 & 0.984 \\
Langmuir & $\mathrm{K}_{\mathrm{L}}$ & 0.204 & 0.008 \\
& $\mathrm{q}_{\mathrm{m}}$ & 121.951 & 21.834 \\
& $\mathrm{R}^{2}$ & 0.125 & 0.752 \\
Temkin & $\mathrm{K}_{\mathrm{T}}$ & 9.883 & 0.281 \\
& $\mathrm{~B}_{\mathrm{T}}$ & 30.048 & 6.675 \\
& $\mathrm{R}^{2}$ & 0.991 & 0.736 \\
\hline
\end{tabular}

The isotherm parameters as presented in Table 1 show the comparison of correlation coefficient for Langmuir, Frieundlich and Temkin models. Frieundlich and Temkin models were more obeyed than Langmuir model which suggested that the adsorption system was heterogeneous.

\section{Conclusion and Recommendation}

In conclusion this study has revealed that removal of $\mathrm{Pb}^{2+}$ and $\mathrm{Ni}^{2+}$ ions from aqueous solutions was established using chitosan powder prepared from snail (Helix pomatia) shells and maximum adsorption was obtained at $\mathrm{pH} 5 \mathrm{for}^{\mathrm{Pb}^{2+}}$ ion and $\mathrm{pH} 7$ for $\mathrm{Ni}^{2+}$ ion with $82.1 \%$ and $68.28 \%$, at a maximum adsorption temperature of $335 \mathrm{~K}$ for $\mathrm{Pb}^{2+}$ ion and $355 \mathrm{~K}$ for $\mathrm{Ni}^{2+}$ ion with $87 \%$ and $80 \%$ metal removal respectively. The study clearly shows that effect of initial metal ion concentration and adsorbent dose on metal adsorption has shown that adsorption increase both the metals with increase in amount of chitosan derived from snail shell with $\mathrm{Pb}^{2+}$ and $\mathrm{Ni}^{2+}$ ions having a maximum adsorption dose of $0.50 \mathrm{~g}$ and $0.75 \mathrm{~g}$ with a $99.93 \%$ and $70.58 \%$ metal removal at contact time showing that the removal efficiency increased with increase in contact time until equilibrium was reached at 180 mins for $\mathrm{Pb}^{2+}$ ion and $\mathrm{Ni}^{2+}$ ion with $99.83 \%$ and $70.37 \%$, respectively. The data from batch studies for the adsorption of $\mathrm{Pb}^{2+}$ and $\mathrm{Ni}^{2+}$ ions showed that pseudo-second order kinetic model was suitable compared to pseudo-first order and the isotherm studies showed that Frieundlich and Temkin models were obeyed unlike Langmuir model going by their correlation coefficient, $\mathrm{R}^{2}$ values.

It is therefore recommend that from the results obtained in this study and field observation during sampling, the following recommendation is been offered;

- The adsorption thermodynamic parameters may be an area of further research in this study.

- Adsorbents used should be regenerated using a suitable regenerating agent and the adsorbents used again.

- The use of alternate methods such as columns or beds is highly recommended.

\section{References}

[1] Ruchita Dixit, Wasiullah, Deepti Malaviya et al., (2015). Bioremediation of Heavy Metals from Soil and Aquatic Environment: An Overview of Principles and Criteria of Fundamental Processes. Journal of Sustainability 7, 21892212; www.mdpi.com/journal/sustainability.

[2] Barkat M, Chegrouche S, Mellah A, Bensmain B, Nibou D, Boufatit M., (2014). Application of

[3] Algerian Bentonite in the Removal of Cadmium (II) and Chromium (VI) from Aqueous Solutions. Journal of Surface Engineered Materials and Advanced Technology, Vol. 4, pp. 210-226.

[4] Morais S, Costa F. G, Pereira M. L., (2012). Heavy Metals and Human Health. Journal of Environmental Health -Emerging Issues and Practice, 978-953-307-854-860.

[5] Fenglian Fu, Qi Wang, (2011). Removal of heavy metal ions from wastewaters: A review, Journal of Environmental Management 92 (3): 407-418.

[6] Ahluwalia S. S, Goyal D., (2007). Microbial and plant derived biomass for removal of heavy metals from wastewater. Journal of Bioresour. Technol., 98, 2243-2257.

[7] Ashutosh Tripathi and Manju Rawat Ranjan., (2015). Heavy Metal Removal from Wastewater Using Low Cost Adsorbents. Journal of Bioremediation and Biodegradation. Volume 6: 315.

[8] Li W, Zhang L, Peng J, Li N, Zhang S. and Shenghui G.,(2008). Tobacco stems as a low cost adsorbent for the removal of $\mathrm{Pb}$ (II) from wastewater: Equilibrium and kinetic studies, Ind. Crop Prod., 28, 294-302.

[9] Ahmaruzzaman Md., (2008). Adsorption of phenolic compounds on low-cost adsorbents: A review, Adv. Colloid Interface Sci., 143, 48-67.

[10] Unlu N. and Ersoz M., (2006). Adsorption characteristics of heavy metal ions onto a low cost biopolymeric sorbent from aqueous solutions, J. Hazard Mate, 136, 272-280.

[11] Crini, G., (2006). Non-conventional low-cost adsorbents for dye removal: a review. Bio-resources Technol. 97 (9), 1061-1085.

[12] Sharma P, Kaur H, Sharma M, Sahore V., (2010). A review on applicability of naturally available adsorbents for the removal of hazardous dyes from aqueous waste. Environ. Monit. Assess., 183, 151-195. 
[13] Cao, J, Tan Y. B, Che, Y. J, and Xin, H. P., (2010). Novel complex gel beads composed of hydrolyzed polyacrylamide and chitosan: an effective adsorbent for the removal of heavy metal from aqueous solution. Bioresource Technol., 101, 2558-2561.

[14] Futalan C. M, Kan C. C, Dalida M. L, Hsien K. J, Pascua C, and Wan M. W., (2011). Comparative and competitive adsorption of copper, lead, and nickel using chitosan immobilized on bentonite. Carbohyd. Polym., 83 (2), 528-536.

[15] Zhou L, Wang Y, Liu Z, Huang Q., (2009) (b). Characteristics of equilibrium, kinetics studies for adsorption of $\mathrm{Hg}$ (II), $\mathrm{Cu}$ (II), and Ni (II) ions by thiourea-modified magnetic chitosan microspheres. Journal of Hazard Mater. 161, 995-1002.

[16] Wan M. W, Kan C. C, Rogel B. D and Dalida M. L. P., (2010). Adsorption of copper (II) and lead (II) ions from aqueous solution on chitosan-coated sand. Carbohyd. Polym., 80 (3), 891-899.

[17] Varma, A. J, Deshpande, S. V, Kennedy J. F., (2004). Metal complexation by chitosan and its derivatives: a review. Carbohydrate Polymers, 55: 77-93.

[18] Ravi Kumar M. N. V, Muzzarelli R. A. A, Muzzarelli C, Sashiwa H. and Domb A. J., (2004). Chitosan Chemistry and pharmaceutical perspectives, Chem. Rev., 104, 6017-6084.

[19] Dutta P. K, Dutta J, Chattopadhyaya M. C, Tripathi V. S., (2004). Jouenal of Polym. Mater. 21, 321-334.

[20] Wan Ngah, Fatinathan W. S., 2010. Journal of Environmental Management, 91, 958.

[21] Sudha P. N., (2010). Chitin, chitosan and derivatives for waste water treatment. In: S.-K. Kim (Ed.), Chitn, Chitosan, Oligosaccharides and their Derivatives. 561- 585.

[22] Wan Ngah W. S, Teong L. C, Wong C. S, Hanafiah M. A. K. M., (2012). Preparation and Characterization of ChitosanZeolite Composites. Journal of applied polymer science Vol. $125,2417-2425$.

[23] Shanmugapriya A, Hemalatha M, Scholastica B and Augustine Arul Prasad T., (2013). Adsorption studies of lead (II) and nickel (II) ions on chitosan-G-polyacrylonitrile. Der Pharma Chemica, 5 (3): 141-155. Scholars Research Library; Available online at www.derpharmachemica.com

[24] Ngah W. S. W, Fatinathan S., (2008). Adsorption of Cu (II) ions in aqueous solution using chitosan beads, chitosan-GLA beads and chitosan-alginate beads. Chem Eng. J. 143, 62-72.

[25] Vasconcelos, H. L., Camargo, T. P., Goncalves, N. S., Neves, A., Laranjeira, M. C. M., Favere, V. T., (2008). Chitosan crosslinked with a metal complexing agent: synthesis, characterization and copper (II) ions adsorption. React. Funct. Polym. 68, 572-579.

[26] Muzzarelli, R. A. A., (2009). Genipin-crosslinked chitosan hydrogels as biomedical and pharmaceutical aids. Carbohydr. Polym. 77, 1-9.

[27] Wu F. C, Tseng R. L and Juang R. S., (2001). Enhanced abilities of highly swollen chitosan beads for colour removal and tyrosinase immobilization, J. Hazard. Mater. 81, 167-177.

[28] Wu, F. C., Tseng, R. L., Juang, R. S., (2001). Kinetic modeling of liquid-phase adsorption of reactive dyes and metal ions on chitosan. Water Res. 35, 613-618.
[29] Kim J. T, Lee D. Y, Oh T. S and Lee D. H., (2003). Characteristics of nitrile-butadiene rubber layered silicate nanocomposites with silane coupling agent, J. Appl. Polym. Sci., 89 (10), 2633-2640.

[30] Rhim J, Hong S, Park H. and Perry K. W., (2006). Preparation and characterization of chitosan-based nanocomposite films with antimicrobial activity, J. Agric. Food Chem. 54, 58145822 .

[31] Wan Ngah, Fatinathan W. S., 2006. Colloid Surf APhysicochem Eng Asp, 277, 214.

[32] Islam Md. M, Md. M. Shah, M. M. Rahman, Md. A. I. Molla, A. A. Shaikh and S. K. Roy, 2011. Preparation of chitosan from shrimp shell and investigation of its properties. Int. J. Basic Appl. Sci., 11 (1): 116-130.

[33] Nawar N, Ebrahim M. and Sami E., (2013). Removal of Heavy Metals $\mathrm{Fe}^{3+}, \mathrm{Mn}^{2+}, \mathrm{Zn}^{2+}, \mathrm{Pb}^{2+}$ and $\mathrm{Cd}^{2+}$ from Wastewater by Using Rice Straw as Low Cost Adsorbent. Academic.

[34] Przemysław Bartczak, Małgorzata Norman, Łukasz Klapiszewski, Natalia Karwan' ska, Małgorzata Kawalec, Monika Baczyn' ska, Marcin Wysokowski, Jakub Zdarta, Filip Ciesielczyk, Teofil Jesionowski., (2015). Removal of nickel (II) and lead (II) ions from aqueous solution using peat as a low-cost adsorbent: A kinetic and equilibrium study. Arabian Journal of Chemistry; doi: 10.1016/j.arabjc.07-18.

[35] Kumar D, Gaur JP., (2011). Metal biosorption by two cyanobacterial mats in relation to $\mathrm{pH}$, biomass concentration, pretreatment and reuse. Bioresour Technol; 102: 2529-2535.

[36] Rathinam A, Maharshi B, Janardhanan SK, Jonnalagadda RR, Nair BU.,(2010). Biosorption of cadmium metal ion from simulated wastewaters using Hypnea valentiae biomass: a kinetic and thermodynamic study. Bioresour Technol; 101: 1466-1470.

[37] Asubiojo OI, Ajelabi, OB., (2009). The removal of heavy metals from aqueous solution by natural adsorbent. Journal of Environental Chemical Toxicology. 91: 883-890.

[38] Choi H. D, Cho J. M, Xang J. S, Lee J. X., (2009). Influence of cationic surfactant on adsorsoption of $\mathrm{Cr}$ (VI) onto activated carbon. J. Hazad. Mater. 161: 1565-1568.

[39] Dhabab JM., 2011). Removal of Fe (II), Cu (II), Zn (II), and $\mathrm{Pb}$ (II) ions from aqueous solutions by duckweed. J. Oceano. Marine Sci. 2 (1): 17-22.

[40] Chowdhury Z, Zain S. M and Rashid A. K., (2010). Equilibrium Isotherm Modeling, Kinetics and Thermodynamics Study for Removal of Lead from Wastewater, J. of Chem. Sci., 8 (1), 333-339.

[41] Abbas S. T, Mustafa M, Al-Faize and Rah A. Z., (2013). Adsorption of $\mathrm{Pb}^{2+}$ and $\mathrm{Zn}^{2+}$ ion from oil wells onto activated carbon produced from Rice Husk in batch adsorption process, Journal. Chem. Pharm. Res., 5 (4), 240-250.

[42] Kamari, A. and Ngah W. S. W., (2009). Isotherm, kinetic and thermodynamic studies of lead and copper uptake by $\mathrm{H}_{2} \mathrm{SO}_{4}$ modified chitosan. Colloid Surface. B, 73 (2), 257-266.

[43] Bhattacharya A. K, Mandal S. N, Das S. K, 2006. Adsorption of $\mathrm{Zn}$ (II) from aqueous solution by using Different adsorbents. Chemical Engineering Journal, 123: 43-51pp. 
[44] Ozer, A. and Ozer, D. (2003). Comparative study of the biosorption of $\mathrm{Pb}$ (II), $\mathrm{Ni}$ (II) and $\mathrm{Cr}$ (VI) ions. Journal of Hazardous Material, 1: 219-229.

[45] Vedia Nüket Tirtom, Ayşe Dinçer, Seda Becerik, TülinAydemir and Ali Çelik., 2012). Removal of lead (II) ions from aqueous solution by using crosslinked chitosan-clay beads. Desalination and Water Treatment 39: 76-82.

[46] Mataka L, Salidu, S, Masamba W and Mwatseteza J., (2010). Cadmium sorption by Moingastenopetala and Moringa oleiferaseed powder. International Journal Environmental Science Technology, 3 131-139.

[47] Kannamba B, and Reddy K. L, Apparao B. V., (2010). Removal of $\mathrm{Cu}$ (II) from aqueous solutions using chemically modified chitosan." Journal of Hazardous Materials, 175, 939948.

[48] Abdel-Ghani N, Hefny M, El-Chaghaby G., (2007). Removal of lead from aqueous solution using low cost abundantly available adsorbents. 4: 67-73.

[49] Sugashini S, Gopalakrishnan S., (2012). Studies on the Performance of Protonated cross linked Chitosan Beads (PCCB) for Chromium Removal. Res J. Chem. Sci. 2 (6): 55-59.

[50] Xiaomin Li, Yanru Tang, Xiuju Cao, Dandan Lu, Fang Luo, enjing Shao., (2008). Preparation and evaluation of orange peel cellulose adsorbents for effective removal of cadmium, zinc, cobalt and nickel, Journal of Colloids and Surfaces A: Physicochemical and Engineering Aspect Volume 317, Issues 1-3, Pages 512-521.

[51] Ramya R, Sankar P, Anbalagan S, Sudha P. N., (2011). Adsorption of $\mathrm{Cu}$ (II) and $\mathrm{Ni}$ (II) ions from metal solution using crosslinked chitosangacrylonitrile copolymer. International journal of environmental sciences Volume 1, No 6.

[52] Reena Malik, Suman Lata et al 2015. Removal of heavy metal from waste water by the use of modified aloe vera leaf powder. International Journal of Basic and Applied Chemical Sciences. Vol. 5 (2) April-June, pp. 6-17.

[53] Santhi T and Manonmani S., (2009). Adsorption kinetics of cationic dyes from aqueous solution by Bioadsorption onto activiated in Environmental sanitation 4 (3): 263-271.

[54] Romera, E, Gonzalez F, Ballester A. and Blazquez Munoz J. A., (2007). Comparative study of heavy metals using different types of algae. Bioresource Technology, 98: 3344-335.

[55] Sheng P. X, Ting Y. P, Chen J. P. and Hong L., (2004). Sorption of lead, copper, cadmium, zinc and nickel by marine algal biomass: Characterization of biosorptive capacity and investigation of mechanisms. Journal of Colloid and Interface Science, 275: 131-141.

[56] Feng N, Guo X, Liang S, Zhu Y, Liu J., (2011) Biosorption of heavy metals from aqueous solutions by chemically modified orange peel. J Hazard Mater; 185: 49-54.

[57] Sha Liang, XueyiGuo, Ningchuanfeng, Qinghua Tian., (2010). Isotherms Kinetics and thermodynamic studies of adsorption of $\mathrm{Cu}^{2+}$ from aqueous solution by $\mathrm{Mg}^{2+} / \mathrm{K}^{+}$type orange peel adsorbents, Journal of Hazardous Materials, 174, 756-762.

[58] Lohani M. B, Singh A, Rupainwar D. C and Dhar D. N., (2008). Studies on efficiency of guava (Psidiumguajava) bark as bioadsorbent for removal $\mathrm{Hg}$ (II) from aqueous solutions, $\mathrm{J}$. of Hazard Mater, 159, 626-629.

[59] Meena, A. K., Mishra, G. K., Kumar, S., Rajagopal, C., and Nagar, P. N. (2003). Adsorption of Ni (II) and Zn (II) from aqueous solution by chemically treated activated carbon. National Conference on Carbon, DMSRDE, Kanpur, pp 31140 .

[60] Hoang V. T, Lam D. T and Thinh N. N., (2010). Preparation of chitosan / magnetite composite beads and their application for removal of $\mathrm{Pb}$ (II) and $\mathrm{Ni}$ (II) from aqueous solution, Mater. Sci. Eng. C, 30, 304-310.

[61] Laus R, Costa T. G, Szpoganicz B. and Fávere V. T., (2010). Adsorption and desorption of $\mathrm{Cu}$ (II), $\mathrm{Cd}$ (II) and $\mathrm{Pb}$ (II) ions using chitosan crosslinked with epichlorohydrin-triphosphate as the adsorbent, J. Hazard. Mater., 183: 233-241.

[62] Mini N. and. Bajpai S. K., (2008). Chitosan-magnetite nanocomposites (CMNs) as magnetic carrier particles for removal of $\mathrm{Fe}$ (III) from aqueous solutions, Colloid. Surface., 320: $161-168$.

[63] Pahlavanzadeh H, Keshtkara R, Safdari J, Abadi Z., (2010). Biosorption of Nickel (II) from aqueous solution by brown algae: equilibrium, dynamic and thermodynamic studies. J Hazard Mater; 175: 304-310.

[64] Malkoc, E. and Nuhoglu Y., 2005. Investigations of Ni (II) removal from aqueous solutions using tea factory waste. Journal of Hazardous Materials, 127: 120-128.

[65] Thilagan J, Gopalakrishnan S and Kannadasan T., 2013. A comparative study on adsorption of copper (ii) ions in aq, ueous solution by; (a) chitosan blended with cellulose and cross linked by formaldehyde (b) chitosan immobilised on red soil, (c) chitosan reinforced by banana stem fibre. International Journal of Applied Engineering and Technology. An Online International Journal Available at http://www.cibtech.org/jet. Vol. 3 (1) January-March, pp. 35-36.

[66] Nour T. Abdel-Ghani and Ghadir A. El-Chaghaby., (2014). Biosorption for metal ions removal from aqueous solutions: a review of recent studies. International Journal of Latest Research in Science and Technology Volume 3, Issue 1: Page No. 24-42.

[67] Naiya TK, Bhattacharya AK, Mandal S, Das SK., (2009). The sorption of lead (II) ions on rice husk ash. Journal of Hazard Mater; 163: 1254-1264.

[68] Mittal A, Mittal J, Malviya A, Kaur D, Gupta VK., (2010.) Adsorption of hazardous dye crystal violet from wastewater by waste materials. Journal of Colloid Interface Sci 343: 463-473.

[69] Febrianto J, Kosasih A. N, Sunarso J, Ju Y. H, Indraswati N, Ismadji, S., 2009). Equilibrium and kinetic studies in adsorption of heavy metals using biosorbent: a summary of recent studies. J. Hazard. Mater. 162, 616-645.

[70] Farhan AM, Al-Dujaili AH, Awwad AM., (2013). Equilibrium and kinetic studies of cadmium (II) and lead (II) ions biosorption onto Ficus carcia leaves. International Journal of Industrial Chemistry; 24.

[71] Abdel-Ghani NT, Hegazy AK, El-Chaghaby G., (2009). Typha domingensis leaf powder for decontamination of aluminium, iron, zinc and lead: Biosorption kinetics and equilibrium modeling. 6: 243-248.

[72] Patil S, Bhole A, Natrajan G,. (2006). Scavenging of nickel (II) metal ions by adsorption on PAC and Babhul Back. Journal of environmental science and energy; 48 (3): 203-208.

[73] Kausar A, Nawaz H, Mackinnon G., (2013). Equilibrium, kinetic and thermodynamic studies on the removal of $\mathrm{U}(\mathrm{VI})$ by low cost agricultural waste. Colloids Surfaces Biointerfaces. 111: 24-13. 